\title{
EM BUSCA DA CIDADE MODERNA: A REMODELAÇÃO URBANA DE SÃo LUÍS DURANTE A ERA VARGAS (1936-1945)
}

Luiz Eduardo Neves dos Santos ${ }^{1}$ Maria Clélia Lustosa Costa ${ }^{2}$

Resumo: O presente artigo versa sobre o processo contraditório de legitimação por um lado de um urbanismo moderno, mas de natureza estatal e autoritária, no contexto de fortalecimento dos municípios brasileiros frente à uma nova realidade urbano-industrial no Brasil dos anos 1930 e 1940. Mais especificamente se detém nas repercussões para o espaço urbano de São Luís, capital do estado do Maranhão, durante a interventoria de Paulo Ramos e da gestão modernizante dos prefeitos Saboya Ribeiro e Pedro Neiva no período varguista. Para tanto, realizou-se uma pesquisa histórica a partir de fontes primárias, como jornais e documentos oficiais da época, com o objetivo de compreender como se deu a remodelação urbana em São Luís.

Palavras-chave: Remodelação urbana. Era Vargas. São Luís.

\section{IN SEARCH OF THE MODERN CITY: THE URBAN REMODELING OF SÃO LUÍS DURING THE VARGAS AGE (1936-1945)}

Abstract: This article deals with the contradictory process of legitimation on the one hand of modern urbanism, but of a state and authoritarian nature, in the context of strengthening Brazilian municipalities in the face of a new urban-industrial reality in Brazil in the 1930s and 1940s. More specifically, it focuses on the repercussions for the urban space of São Luís, capital of the state of Maranhão, during the intervention of Paulo Ramos and the modernizing management of mayors Saboya Ribeiro and Pedro Neiva in the Vargas period. To this end, a historical research was carried out from primary sources, such as newspapers and official documents of the time, with the aim of understanding how this urban remodeling took place in São Luís.

Keywords: Urban remodeling. Vargas age. São Luís.

\section{EN BUSCA DE LA CIUDAD MODERNA: LA REMODELACIÓN URBANA DE SÃO LUIS DURANTE LA ERA VARGAS (1936-1945)}

Resumen: Este artículo aborda el processo contradictorio de legitimación por un lado del urbanismo moderno, pero de carácter estatal y autoritario, enel contexto del fortalecimiento de los municípios brasileños frente a una nueva realidad urbanoindustrial en Brasil em los años treinta y cuarenta. Más específicamente, se centra em las repercusiones para el espacio urbano de São Luís, capital del estado de Maranhão, durante la intervención de Paulo Ramos y la gestión modernizadora de los alcaldes Saboya Ribeiro y Pedro Neiva em el periodo Vargas. Con este fin, se realizó una investigación histórica a partir de fuentes primarias, como periódicos y documentos oficiales de la época, conel objetivo de compreender cómo se llevó a cabo esta remodelación urbana en São Luís.

Palabras clave: Remodelación urbana. Era Vargas. São Luís.

\footnotetext{
${ }^{1}$ Universidade Federal do Maranhão (UFMA), Departamento de Ciências Humanas, Pinheiro, Brasil, luiz.neves@ufma.br, https://orcid.org/0000-0002-1204-6626

'Universidade Federal do Ceará (UFC), Departamento de Geografia, Fortaleza, Brasil, clelialustosa@gmail.com, http://orcid.org/0000-0001-5066-4209.
} 


\title{
Introdução
}

Nas primeiras três décadas do século passado, o Brasil possuía uma população rural majoritária, mergulhada no analfabetismo, com baixa expectativa de vida e essencialmente empobrecida. A economia era sustentada pelo seu principal produto de exportação, o café, que representava mais de $80 \%$ das exportações do país à época (IANNI,2010).

Nas décadas de 1920 e 1930, o cenário,o processo e as condições socioeconômicas e culturais no Brasil caminharam para o incremento de um novo projeto nacional, com a instauração de um emergente paradigma moderno, que encontrou nos centros urbanos - territórios que começavam a se diversificar - seu grande laboratório.Segundolanni (2010), é a partir da década de 1930 que são estabelecidas, sob a responsabilidade do Estado, as condições e os limites básicos de funcionamento do mercado da força de trabalho. Na mesma linha de pensamento, Francisco de Oliveira afirmaque:

\begin{abstract}
a revolução de 1930, que teve em Oliveira Viana e Francisco Campos dois de seus principais elaboradores na sequência do Estado Novo, atendeu às petições autoritárias, ampliando o quadro de institucionalidade, uma poderosa anabolização do Estado, dando-Ihe condições e instituições para administrar e regular o capitalismo moderno, intervindo no conflito de classes, reorganizando os poderes nas entidades federadas para anular 0 justamente temido poder oligárquico-clânico (OLIVEIRA, 2005, p. 381).
\end{abstract}

Dessa forma, a política econômica brasileira pós-1930, através do poder do Estado, muito contribuiu para a expansão e funcionamento do capitalismo monopolista no país em condições de dependência, já que os Estados Unidos iniciavam sua política imperialista na América Latina. O conjunto das atividades estatais no período 1930-1945 assinalou a agonia do Estado Oligárquico ${ }^{3}$ (IANNI, 2010). As medidas econômicas e políticas adotadas nesse período e a própria reestruturação do aparelho estatal tiveram um caráter modernizante, desenvolvimentista e de apelo ao nacionalismo.

A Revolução de 1930 no Brasil provocou embates e contradições no cenário político maranhense e ludovicense, pois havia no Estado do Maranhão uma hegemonia de grupos oligárquicos que controlavam as instituições políticas, além da debilitada economia. Tais grupos mantinham relações com lideranças coronelistas por todo o Maranhão, forçando produtores rurais de menor porte a ter forte dependência política e econômica. Havia também, principalmente na capital São

${ }^{3}$ Entendido aqui como Estado agrário e tributário, cuja elite emanava das classes dominantes tradicionais, e cujo monopólio do poder político servia exclusivamente para o enriquecimento dos membros de sua própria classe social. 
Luís, uma elite comercial e industrial que mantinha fortes vínculos com setoresagrícolas do interior do Estado.

As mudanças impostas pelo emergente cenário político nacional forçavam o rompimento com as estruturas tradicionais existentes, mas em terras maranhenses os "grupos políticos tradicionais continuaram mantendo suas zonas de influência, com poucas alterações. Permanecia a união de seus interesses, juntamente com os dos comerciantes que chefiavam o oligopólio da Praia Grande" (COSTA, 2016, p. 62-63), base econômica estadual através do porto. Cabia às novas lideranças dinamizar esse sistema a partir de reformasprogressistas.

Diante do exposto, o presente artigo tem o objetivo de analisar o processo contraditório de legitimação por um lado de um urbanismo moderno, mas de natureza estatal e autoritária, no contexto de fortalecimento dos municípios brasileiros frente à uma nova realidade urbano-industrial no país. Mais especificamente se detém nas repercussões para o espaço urbano de São Luís a partir da interventoria do Paulo Ramos no Maranhão e da gestão municipal dos prefeitos Saboya Ribeiro e Pedro Neiva no período varguista.

\section{Da Primeira República à Era Vargas e a questão do Urbanismo}

A Primeira República ou República Velha (1889-1930), sobretudo a partir dos anos 1920, se caracterizou, do ponto de vista socioespacial, pela dinamização e expansão das cidades e da indústria, impulsionados pela imigração estrangeira e por uma política de substituição de importações. A crise na agricultura e a imigração fez com que houvesse um maior deslocamento para as nascentes cidades, "além de camponeses, entraram no país pedreiros, padeiros, sapateiros e pequenos comerciantes - diversificando o quadro de serviços urbanos" (SCHWARCZ; STARLING, 2015, p. 326). Embora a população rural fosse maior e a agricultura a principal atividade econômica do país, não se pode negar que nas três décadas iniciais do século $X X$, os modos de vida urbano começavam a ganhar destaque.

As cidades precisavam ser cuidadas e embelezadas, para que representassem bem sua função de ser o sustentáculo da economia agroexportadora, para tanto, as cidades brasileiras foram objeto de reformas urbanísticas, com a função

voltada para a otimização do funcionamento do complexo agroexportador. As grandes transformações urbanas são realizadas procurando, entre outras coisas, evitar a interrupção do funcionamento dos portos brasileiros, como quando diversas epidemias tomaram conta das cidades litorâneas, principalmente a partir de 1860 (QUINTO JUNIOR, 2003, p. 187). 
Desta forma, com o incremento de uma realidade urbana, surge de maneira mais efetiva no Brasil os chamados Códigos de Postura, que continham determinações de cunho comportamental, de condutas e ordenamento do espaço urbano, seja do ponto de vista das construções de imóveis, da salubridade e da higiene - com o objetivo de controlar epidemias como a peste, a varíola e a febre amarela - mas, sobretudo iniciava pelo controle dos corpos, investindo nos aspectos mais relevantes para gerir a vida na urbe, organizando a vida social, esse mecanismo remete à ocorrência de táticas e técnicas do biopoder 4 .

O disciplinamento da população foi indispensável ao florescimento capitalista brasileiro, modo de produção que só pôde se desenvolver às custas da inserção controlada dos corpos nos meios de produção e através de um ajustamento de fenômenos de população aos processos econômicos.

É possível afirmar que os códigos de postura formulados em larga escala no Brasil entre as últimas décadas do Oitocentos e as primeiras décadas do século passado são o ponto de partida do que posteriormente se convencionou chamar de plano diretor e zoneamento, que se espalharam pelo país a partir da segunda metade do século $X X$.

É necessário relembrar que as tentativas expostas em planos e códigos das cidades brasileiras no que diz respeito ao embelezamento de seus núcleos se vinculam a uma imposição ideológica das classes dominantes, que "não era discurso apenas; refletia ação concreta do Estado, embora com objetivos nem sempre condizentes com o discurso" (VILLAÇA, 2010, p. 192). Era a época das grandes reformas urbanas vinculadas ao paradigma higienista, com saneamento, abastecimento d'água, cuidado com os resíduos sólidos e abertura de grandes avenidas para circulação de ar.

A São Luís da segunda metade do século XIX e primeiras décadas do século XX, bem como outras cidades brasileiras,viu a produção de diversos Relatórios feitos por médicos sanitaristas e engenheiros com o intuito de diagnosticar os problemas urbanos e sua influência sobre a saúde da população, com destaque para o estudo sobre Saneamento produzido por Palmério Cantanhede em 1899 e um relatório sobre a peste bubônica feito por Victor Godinho em 1904.

\footnotetext{
4 "As disciplinas do corpo e as regulações da população constituem os dois polos em torno dos quais se desenvolveu a organização do poder sobre a vida. A instalação, durante a época clássica, desta tecnologia de duas faces - anatômica e biológica -, individualizante e especificamente, voltada para os desempenhos do corpo e encarando os processos da vida, caracteriza um poder cuja função mais elevada já não é mais matar, mas investir sobre a vida, de cima para baixo" (FOUCAULT, 2018, p. 150).
} 
Nos anos 1920, com o florescimento e a diversificação das relações sociais urbanas, houve o surgimento de novos grupos sociais que tinham interesses distintos dos grupos predominantes na época, estes últimos representavam uma elite política ligada aos grupos oligárquicos regionais que praticavam uma

política econômica externa, do tipo liberal (exigida por empresas comerciais
e financeiras europeias e norte-americanas que controlavam o setor externo
brasileiro) que significava a maciça e sistemática exportação do excedente
nacional através da comercialização do café e a importação de
manufaturados e artigos de consumo para a classe dominante, ou seja, boa
parte do produto nacional encaminhava-se para o exterior (IANNI, 2010, p.
28).

Os novos grupos sociais eram diversos, consequência da incipiente industrialização (burguesia industrial), expansão do setor terciário e da própria urbanização. A fundação do Partido Comunista do Brasil (PCB) em 1922, as primeiras manifestações do tenentismo e a Semana de Arte Moderna (1922) são algumas expressões desses novos grupos.

Antes de 1930, o sistema político-econômico no Brasil já mostrava claros sinais de desgaste, problemáticas estruturais e conjunturais típicas de uma economia dependente e frágil. Dois acontecimentos foram cruciais para a República Velha implodir, primeiro a Grande Depressão de 1929 que provocou graves danos à cafeicultura, segundo, o assassinato de João Pessoa que culmina no agravamento da crise política nacional, levando à deposição do presidente Washington Luís (sem que ele passasse o cargo ao seu sucessor Júlio Prestes). Em 3 de novembro de 1930 uma Junta Governativa Provisória, formada pelos generais Tasso Fragoso e Mena Barreto e o Contra-Almirante Isaías de Noronha entregou o poder ao líder da Aliança Liberal, Getúlio Vargas (SCHWARCZ; STARLING, 2015).

Com a Revolução de 1930, inaugura-se no Brasil uma estratégia governamental com diretrizes nacionalista e intervencionista, uma tecnoestrutura estatal (IANNI, 2010) de forte planificação administrativa, com repercussões na política econômica e nas reformas urbanas, sinais claros da ruptura com os modelos que vigoraram nas primeiras três décadas do século XX. Vargas implementa uma gestão modernizante, porém autoritária, atingindo seu auge com o golpe de 10 de novembro de 1937. As cidades e seus modos de vida seriam o novo lócus da modernidade preconizada por Getúlio Vargas.

A nova racionalidade política a partir de 1937 no Brasil passava obrigatoriamente pelo controle das cidades, com projetos de modernização, Planos de Remodelação e Extensão (LEME, 2005) e Planos Diretores e Zoneamentos. 
Planos que incluíam demolições de construções e higienização de diversos territórios, o que suscitou desigualdades através da segregação socioespacial.

Pode-se afirmar que o par modernidade-autoritarismo parte de um mesmo processo, a intenção do urbanismo para a cidade varguista era fomentar uma nova estética, atraente no discurso, instrumento propagandista do seu regime político e eficiente do ponto de vista da engenharia e da arquitetura com seus novos paradigmas científicos. Os Institutos de Aposentadoria e Pensão (IAP's), ligados à administração direta e indireta do governo, por exemplo, constituíram o grande inventário arquitetônico estadonovista, mas segundo Manzo (2011), as edificações que melhor representaram a imagem do poder de Getúlio Vargas, no tocante à onipresença do Estado na vida dos cidadãos, na solidez de sua estrutura e na segurança e confiança perante os compromissos firmados, na ratificação do conceito de nação pelas suas tradições e ao mesmo tempo de modernidade, foram as dos Ministérios, edifícios modernos e imponentes.

A seguir, se discutirá o papel da Interventoria de Paulo Ramos no Maranhão, com destaque para as administrações municipais de Saboya Ribeiro e Pedro Neiva e suas relações com o urbanismo em São Luís.

\section{Os desafios de Paulo Ramos e Saboya Ribeiro frente a uma cidade decadente}

A política que simbolizava a mudança no Brasil dos anos 1930 era representada pela indicação de interventores nos Estados, que poderiam ser naturais dos próprios Estados ou não. Desde o início desta política até 1936, houve tanto mudanças na gestão municipal e estadual via imposição do governo federal, quanto uma rotatividade de militares de linha dura para atuarem como interventores no Estado, o que por vezes provocou tensões com grupos políticos de oposição locais. O Governo Federal, no ano de 1936, indicou então o advogado maranhense de Caxias, Paulo Martins de Souza Ramos, para assumir o cargo de Interventor Federal no Maranhão. Seu nome foi consenso entre os políticos locais, mesmo entre os grupos de oposição ao governo Vargas.

Ramos promoveria o que se chamou na época de 'a reconstrução do Maranhão', inaugurando um período “dos mais profícuos e progressistas que já desfrutou o Maranhão" (MEIRELES, 2002, p. 336). Essa concepção de Meireles, um tanto ufanista, é reforçada pela indicação do nome do engenheiro e urbanista cearense José Otacílio de Saboya Ribeiro para ser prefeito de São Luís. Havia na mentalidade na época, desde intelectuais e também entre as lideranças políticas 
locais e nos quadros políticos nacionais a ideia de que o perfil técnico de um líder representado por Saboya Ribeiro ${ }^{5}$ - seria capaz de levar adiante o projeto modernizador preconizado por Vargas.

Figura 01 - Paulo Ramos e Saboya Ribeiro

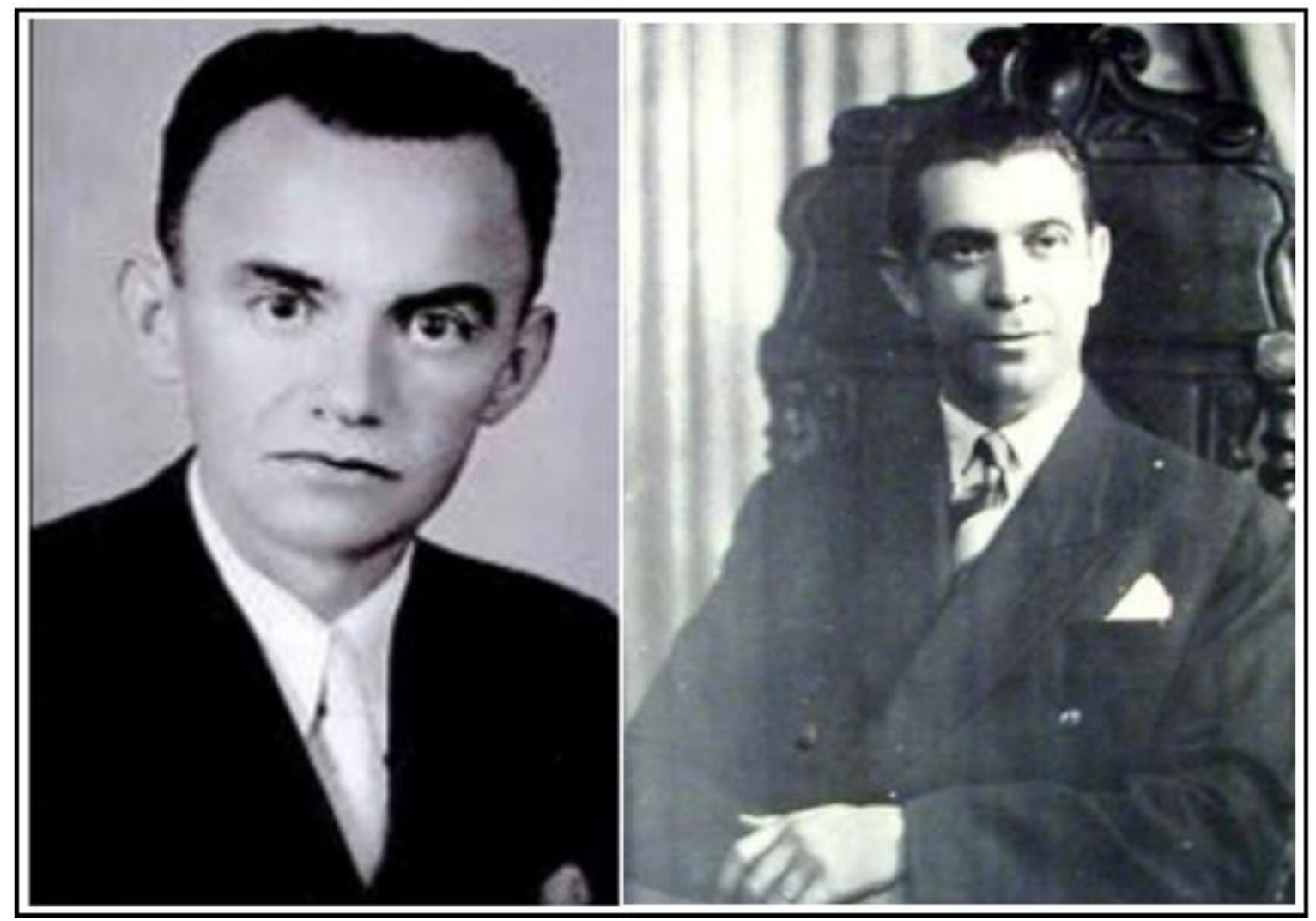

Fonte: Ferreira (1987) e Arquivo da Biblioteca DAU/UFC.

Antes de se analisar a importância de Paulo Ramos, Saboya Ribeiroe Pedro Neiva para uma mudança na concepção da cidade de São Luís na segunda metade dos anos 1930, instaurando um paradigma urbano moderno, cabe destacar um texto de Josué Montello sobre São Luís publicado na Revista Careta em novembro de 1937, intitulado "A cidade que não quer ser nova", em tom ufanista, o jovem escritor frisa o marasmo de uma cidade que se recusava ser moderna.

Todas as cidades no Brasil se transformam. Um ritmo vertiginoso as envolve. Fortaleza, por exemplo, há pouco tempo, valia apenas por sua praia muito alva, povoada pelos heróis do poeta maior da prosa brasileira. Hoje é um espetáculo dinâmico. Os prédios se empinam no dorso dos alicerces de cimento armado e os arranha-céus se multiplicam sob o sol doirado da terra de Iracema. Belém, mais ao norte, embrulhada nas suas mangueiras, tem já o aspecto das grandes cidades. Há movimento, inquietação, vontade louca de subir (...) São Luís, entretanto, é aquilo mesmo, minha cidade querida não muda (MONTELLO, 1937, p. 24).

\footnotetext{
${ }^{5}$ Saboya Ribeiro, antes de ser prefeito de São Luístrabalhou na Secretaria de Viação e Obras do Rio de Janeiro, onde exerceu o cargo de Engenheiro-Chefe do 5.. trecho da nova adutora do rio das Lages. Foi prof. de Arquitetura na Faculdade Nacional de Arquitetura da Universidade do Brasil, onde substituiu Atílio Corrêa Lima, em 1937. Foi diretor da Escola Nacional de Belas-Artes (LOPES, 2013).
} 
Apesar do tom saudosista, utilizando-se de expressões no texto como "minha cidade querida”, "a heroica e leal São Luís de La Ravardière", Montello não deixa de possuir uma certa razãoem seu artigo; São Luís na segunda metade dos anos 1930 ainda estava limitada ao que se conhece hoje como o anel viário, que circunda a área central e histórica da cidade e mesmo dentro deste perímetro, em suas margens, ainda havia lugares com características essencialmente rurais.

Pelo exposto, coube a Paulo Ramos, que assumiu o cargo de interventor em agosto de 1936, a Saboya Ribeiro, empossado prefeito em 15 de setembro daquele mesmo ano, e a Pedro Neiva, substituto de Saboya Ribeiro na metade do ano de 1937, o desafio de romper com essa falta de modernização e desenvolvimento urbano em São Luís. Esses três nomes seriam responsáveis pela elaboração e execução de um Plano de Remodelação para São Luís, ambicioso na teoria, que encontrou limitações práticas por causa das dificuldades financeiras, mas não deixou de causar inovações na cidade de então.

Em seu diagnóstico sobre São Luís, Saboya Ribeiro constatou primeiramente uma imagem negativa sobre uma cidade antiga e pouco higienizada, falou em mensagem dirigida à Câmara Municipal, quando da sua saída do cargo de prefeito, que os desafios eram grandes em reformar uma cidade bonita, porém, decadente, talvez a única capital do Brasil que conservara um conjunto de casario do século XIX, com suas vias tortuosas, estreitas e íngremes e com seus velhos trapiches (SABOYA RIBEIRO, 1937).

O então prefeito concebia a cidade como um organismo vivo que deveria ter saúde, para assim se desenvolver, e para tanto tratou de declarar guerra aos espaços insalubres e degradados ${ }^{6}$ em São Luís. Sobre a questão da higiene, ele aponta em seu diagnóstico problemas sociais e estéticos, que poderiam ser melhorados pela demolição de ruínas da cidade; disse ele que "não é pequeno o número de prédios que se encontram em estado adeantado de ruina, transformados

\footnotetext{
${ }^{6} \mathrm{Na}$ Edição de 1. de junho de 1937, em sua página 2, o Jornal O Imparcial estampava a seguinte manchete "As Obras de Demolição dos Pardieiros de S. Luiz", o texto era um relato claro do combate ostensivo que Saboya Ribeiro fez para pôr fim em áreas degradadas de São Luís. Ele foi escrita assim: "Sabado pela manhan, o nosso reporter encontrando-se na Praça João Lisbôa com o Sr. Francisco de Paula Gomes, mestre de obras da Prefeitura Municipal, o qual se dirigia para as obras de demolição, que o Dr, Saboya Ribeiro está mandando proceder nos velhos pardieiros que ameaçam dia a dia abafar os transeuntes da nossa capital. (...) Dirigimo-nos então para o enorme sobrado da Rua Cândido Mendes, 387, onde arriscadamente trabalhadores promovem a sua demolição (...) precisamente dentro de 3 semanas o enorme sobrado estará transformado em esqueleto (...) Depois dessa demolição o Dr. Saboya Ribeiro atacará os serviços em outros prédios velhos, no correr da Ulen que estão em vias de desabar. O prefeito, zeloso pela vida dos habitantes daquelles pardieiros, está intimando-os a se retirarem dos mesmos. Sabemos que muitos desses habitantes, apesar das intimações continuam a habitar os prédios em apreço".
} 
em fócos de proliferação de animaes nocivos a saude, ameaçando permanentemente a vida dos transeuntes" (SABOYA RIBEIRO, 1937).

Saboya Ribeiro criticou veementemente a especulação imobiliária que se realizava na zona central, em que proprietários exploravam a pobreza pela cobrança de aluguéis caros em albergues sujos. Segundo ele

É possível que os que aqui vivem se tenham acostumado ao aspecto das fachadas mal cuidadas, dos beiraes sujos e de mal apparencia geral das ruas. Mas os que aqui aportam pela primeira vez, não deixam de experimentar uma sensação de tristeza e de desalento, de notar que os oitões das edificações pintadas de negros ou cobertos de limo, emprestam uma nota fúnebre ao panorama da cidade (SABOYA RIBEIRO, 1937).

Ainda em seu diagnóstico sobre São Luís, a visão de Saboya Ribeiro era de que a cidade poderia passar por reformas de maneira menos dolorosa, já que a intervenção na cidade existente e antiga poderia ser alcançada através de planos de fácil execução, o que traria um desenvolvimento civilizatório, numa cidade "onde não existe cultura generalisada e onde é sentida de maneira forte, a falta de sopro do progresso realizador" (SABOYA RIBEIRO, 1937). Para sustentar seus argumentos, o engenheiro-arquiteto cearense seguiu uma linha parecida com a feita por Montello em seu texto para a revista Careta, ao fazer comparação com outras cidades brasileiras:

Porto Alegre, a bella cidade sulina, marcha a passos gigantescos; a velha capital bahiana caminha sob novos rithmos; as cidades Pernambucanas, mesmo as do alto sertão, organisam planos de extensão e embellezamento; o architecto Nestor de Figueiredo orienta traçados das cidades Parahybanas e mostra novos caminhos à cidade de Fortaleza; Bello Horizonte, a jovem capital mineira, construidaha menos de meio seculo, no momento, sob a orientação de Octacilio Negrão, soffre uma como que verdadeira remodelação (SABOYA RIBEIRO,1937).

Ele também se disse espantado com o estado de abandono da cidade, que nunca passara por uma "remodelação systematica ou melhoramento extensivo" (SABOYA RIBEIRO, 1937) e colocava culpa na elite política e econômica local, chamando-a de individualista, que nada fazia para obrigar a todos a zelar pela cidade. Destarte, é possível afirmar que as pretensões de Saboya Ribeiro eram audaciosas ao objetivar uma reforma urbana alicerçada no higienismo e na mudança de comportamento dos habitantes perante o espaço urbano.

Para tanto, propôs uma grande reforma administrativa e aprovou um novo, abrangente e audacioso Código de Posturas em menos de dois meses como prefeito. Foi o mais abrangente código da história da cidade. Através do Decreto n.ํำ 205, de 3 de novembro de 1936, idealizado e promulgado por Saboya Ribeiro, entra em vigor o novo Código de Posturas de São Luís, acabando com um atraso de cerca 
de 43 anos desde a publicação do último Código em 1893. No início do Código que acabara de ser aprovado, existiam explicações para a renovação da legislação:

(...) Considerando que o progresso da technicapoz à disposição das cidades elementos inteiramente para os quaes é necessário crear legislação,(...)Considerando que a prática nas capitaes brasileiras tem forçado as Municipalidades [...] a adotarem novos Códigos compatíveis com a épocha atual, e completa-los com elementos novos [...] assim, constituindo uma [...] difficil consulta,(...)Considerando que a Municipalidade de à muito se resente de um Código [...] dotar a cidade de São Luiz de um novo Código, [...] com as exigências do progresso doBrasil,Art. Único Decreta e manda pôr em execução o novo Código de Posturas do Município de São Luiz, revogadas as disposições em contrário. (SELBACH, 2010, p. 97-98).

As primeiras palavras da lei chamam a atenção para a necessidade de sua renovação em vistas do progresso técnico, exigindo dos municípios e capitais brasileiras a se adaptarem aos novos tempos em decorrência também das mudanças nos hábitos, comportamentos e mentalidades da sociedade.

O novo Código foi dividido em 27 títulos, alguns com respectivas seções, conforme a necessidade do assunto. O total de artigos chegou a 508, o maior e mais detalhado entre os cinco códigos de posturas que já existiram em São Luís no intervalo de mais de um século.

O primeiro assunto tratado no Código se referia às infrações, das multas e das penas. O segundo tratava das questões propriamente urbanas, dividido entre os títulos II a VIII, entre os artigos 19 a 85. O Título II tratava do Município, dos bens de uso comum e dos terrenos, sendo dividido em dois capítulos, da Divisão administrativa no artigo 19, estabelecendo as bases para o zoneamento da cidade que seria aprovado pouco mais de um depois. Nele há a divisão em 4 zonas a saber: Central, Urbana, Suburbana e Núcleos do Interior da Ilha e Rural.

Tratou ainda de logradouros públicos e das Ruas, estabelecendo as larguras e comprimentos, estabeleceu regras para a urbanização de novas áreas e sua divisão em lotes, determinou condições para arborização e abriu possibilidades para regulamentar o uso nas estradas municipais. Tratou da tecnologia urbana definindo muitas expressões do urbanismo da época como "Edificar", "Construir", "Fundo de Lote", "Porão", "Prédio de Sobrado", "Logradouros Públicos”,entre outras. Na lei, apareceu pela $1^{\underline{a}}$ vez a palavra "Zoneamento" e "Zonas", assim descritas:

Zoneamento - É a divisão da cidade em diversas zonas ou districtos de uso estabelecido num plano de cidade, afim de promover a localisação racional dos seus differentes órgãos, propocionando aos seus moradores vantagens de ordem econômica, sanitária, esthetica, mediante restricções quando ao uso e volume das edificações.

Zona - São os diferentes districtos de uma cidade, estabelecidos num zoneamento. Essas zonas são:

a) Residenciaesque podem ser subdivididas em zona de habitações 
particulares, zonas de habitações colletivas, zonas mixtas, etc., onde é permitido o commercio de gêneros de uso diário destinados á alimentação de famílias e uso domestico, pequenas officinas eatelleres.

b) Zona Commercial que abrange em particular o movimento commercial, interno e externo, da cidade, abrangendo o commercio em varejo (lojas de fazenda, armarinhos, perfumarias, drogarias, etc.), o centro de negócios (bancos, casas bancarias, corretores, bolsas)etc.

c) Zona Industrial onde se grupam as differentesindustria podem ser classificadas segundo a sua natureza em diversos grupos e esses grupos formarão sub-zonas cada qual adequada a seu destino. Da zona industrial fazer parte também o porto, o aero porto, as estações de estradas de ferro, villas e casas operarias quando convenientemente dispostas ao serviço das differentes industrias. (SELBACH, 2010, p.118-119).

É possível perceber que neste Código, Saboya Ribeiro lança as bases de um planejamento urbano mais moderno e arrojado, estabelecendo uma visão de urbanização para os próximos anos de acordo com a vocação social e econômica. Desta forma, a fim de organizar a expansão urbana em direção às periferias e áreas rurais, "às margens das linhas de bonde, o Código subordina a iniciativa privada ao 'Plano de Urbanização' e estabelece índices de ocupação e dimensionamento para novos loteamentos, prevendo um alcance regional" (LOPES, 2013, p. 183). Saboya Ribeiro anteviu o direcionamento futuro da cidade, para onde ela caminharia.

Outras partes do Código tratavam ainda dos profissionais urbanos, tais como arquitetos, engenheiros, arquitetos construtores e construtores, do alinhamento, localização e nivelamento, das construções em geral, dividido em quatro seções: pés direitos, altura dos edifícios, áreas de iluminação e ventilação, e serventias em comum; e arquitetura das fachadas, marquises e toldos, andaimes e tapumes. Outro assunto abordado foram as questões sanitárias, especialmente as voltadas aos espaços físicos, como as condições de salubridade e higiene gerais dos subterrâneos, porões e sobrelojas, cavas, Porões, Lojas e Sobrelojas.

O Título $X$ tratava dos estabelecimentos industriais e comerciais, dividindo-se em sete Seções: Açougues; Fábricas de produtos alimentícios, farmacêuticos, laboratórios e indústrias leves ocupando menos de 50 pessoas; Fábricas; Hospitais; Cocheira e estábulos, Escolas; e Garagens, postos de gasolina e lubrificação.

O Código de 1936 estabeleceu critérios rigorosos e bem definidos sobre projetos arquitetônicos e urbanísticos que envolviam embelezamento, segurança ventilação, salubridade, higiene, tamanhos de vias, estética urbana, fachadas de prédios, tipos de construções, dentre outros. A lei determinava "que cópias dos projetos fossem enviadas à Diretoria de Saúde Pública do Estado e citava também o Serviço de Salubridade das Edificações" (LOPES, 2013, p. 185). Portanto, 
obedecendo, de forma coerente, a outras instâncias no que dizia respeito às fiscalizações.

Outros dois Decretos vieram somar com o Código de Posturas em 1936,

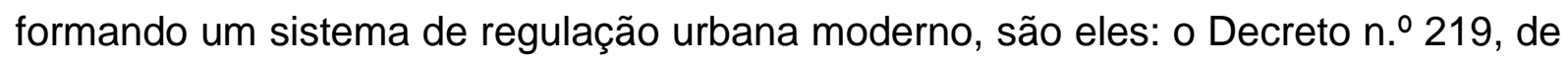
19 de dezembro, e o Decreto $n . \stackrel{0}{217}$, de 19 de dezembro. Eles tratavam de um novo Regime Tributário e de um pioneiro zoneamento (mapa da figura 2), respectivamente.

A reformulação tributária estabeleceu novas taxas para obras e construções em diferentes territórios da cidade ou zonas que acabavam de ser criadas, além dos melhoramentos urbanos. O título $7^{\circ}$, intitulado 'Taxas Sobre os Serviços Municipais', determinava a criação da "taxa de limpeza, jardins, iluminação e conservação das vias públicas", bem como criava taxas para "melhoramentos na cidade".

Essa estratégia era uma maneira de aumentar a arrecadação de um Estado com graves problemas nas finanças, mas que pelas mãos de Paulo Ramos, a partir de sua experiência como funcionário público no Ministério da Fazenda e com sua habilidade de diálogo com o Legislativo e com nomes dos altos cargos da política nacional, conseguiu apoio para equilibrar as contas do Estado. Segundo Costa (2016, p. 80):

\begin{abstract}
A solução fiscal de questões, que desde a primeira metade do século $X X$ afligiam aos administradores era efusivamente comemorada, sobretudo no que se referia a recuperação da capacidade de pagamento do Estado, tanto no Brasil quanto no estrangeiro. Ramos comemorava juntamente com os deputados estaduais os resultados da reforma da contabilidade pública e do sistema tributário (mediante lei estadual aprovada) e da resolução das dívidas interna, externa e flutuante, passando pelos empréstimos tomados nos Estados Unidos e na Europa, bem como pela criação do Banco do Estado.
\end{abstract}

Junto com a questão da tentativa de sanar o problema fiscal nas contas públicas do município, Saboya Ribeiro edita um decreto na mesma data do novo regime tributário (19 de dezembro de 1936), que é o zoneamento, baseado no que estava determinado no Artigo 19 do Código de Posturas aprovado 46 dias antes.

O zoneamento proposto por Saboya Ribeiro coincidia "com o traçado urbano representado no mapa da cidade desenhado por José Abranches de Moura dez anos antes" (LOPES, 2013, p. 180). Esta pioneira divisão do município considerava, além da zona mais adensada de São Luís (Zonas Central e Urbana), os núcleos suburbanos da ilha (Zona Suburbana), ocupações que apresentavam incipientes características urbanas, mas que eram cercadas de sítios, quintas e chácaras, como os povoados do Anil, São José, Pedrinhas, Paço do Lumiar, Olho D’água e Turu. Tal 
zoneamento identificava ainda todo o resto da ilha, em sua maioria ZonaRural.

Figura 02 - Mapa baseado no Decreto ํo 217/1936 que instituiu o Zoneamento

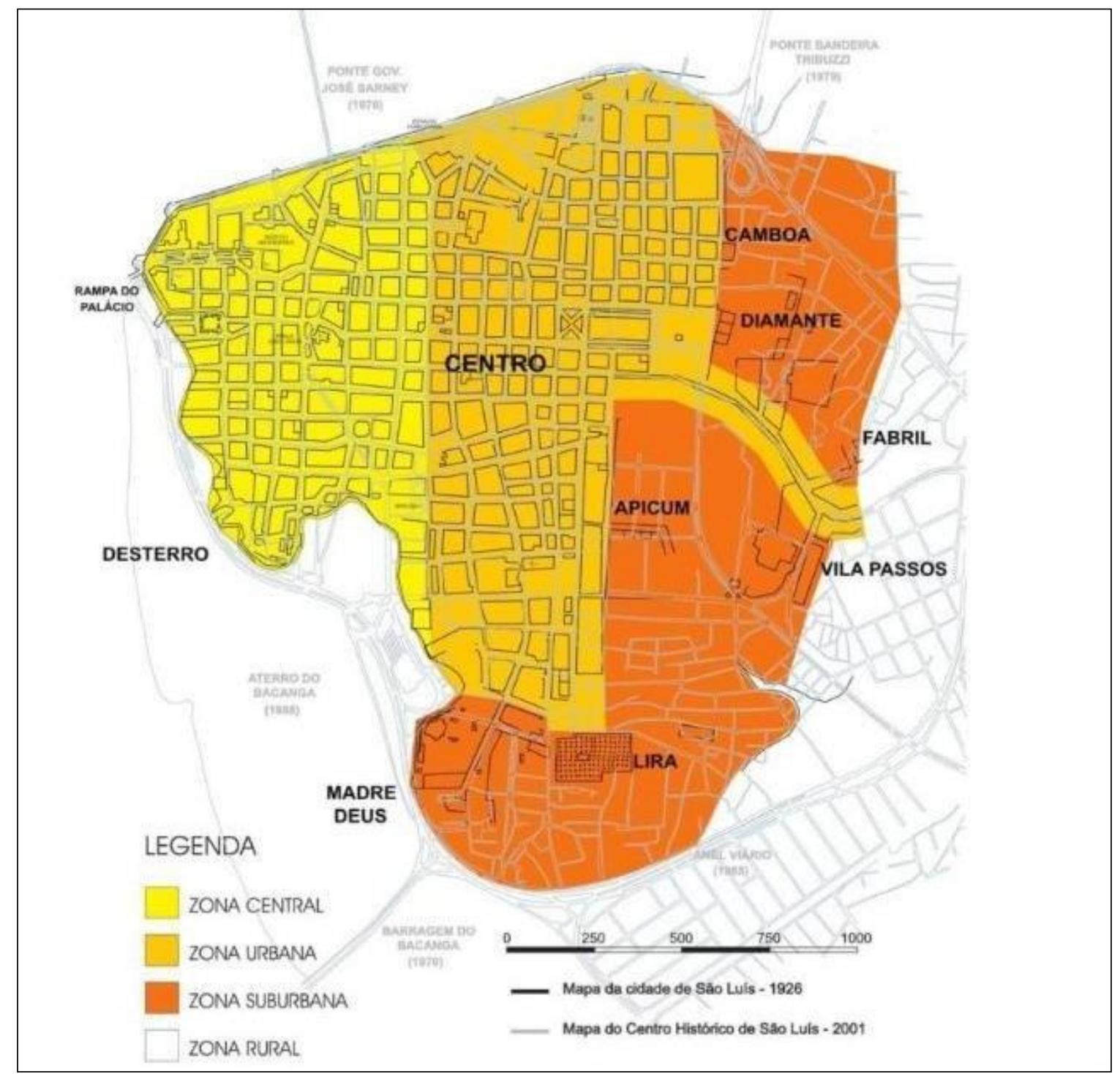

Fonte: Lopes (2013, p. 178).

Em fevereiro de 1937, Saboya Ribeiro ainda apresentou um 'ante-projeto de remodelação da cidade' que unia questões e aspectos socioeconômicos em prol do desenvolvimento urbano e algumas soluções urbanísticas. Habitação popular, salubridade, intervenções urbanas a partir de investimentos privados, barateamento nas construções através dos materiais e a criação de um hotel estavam incluídos. 
Figura 03 - Croqui do Plano de Remodelação de São Luís elaborado por Saboya Ribeiro

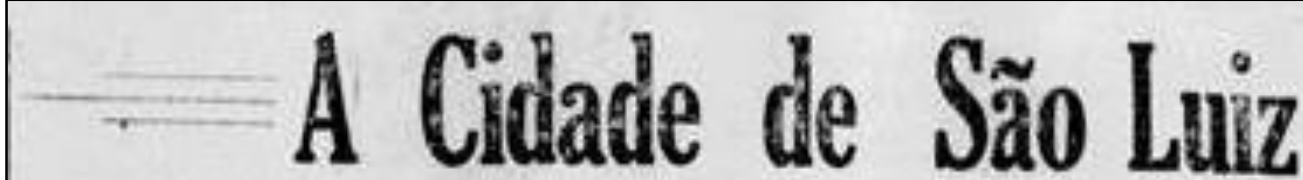

Completando as informaçées M. Novo, corlando a Z ladusIue nes tém sido possivel co-tral até o Caes do Porto, (Larther sobre a administreçáo mu- kura 24 ms.).

C.SPS:

Arenida V. Maúá constitui a caes de cabotagem, Gestiiar nicupal. publicamos a pianta Av. La Ravardiere: Comeca a cabotagem do Esiado. da cídade de S. Laiz, a cuju de no Lisbea, segue ra Cel. Av. Candido Ribeiro,

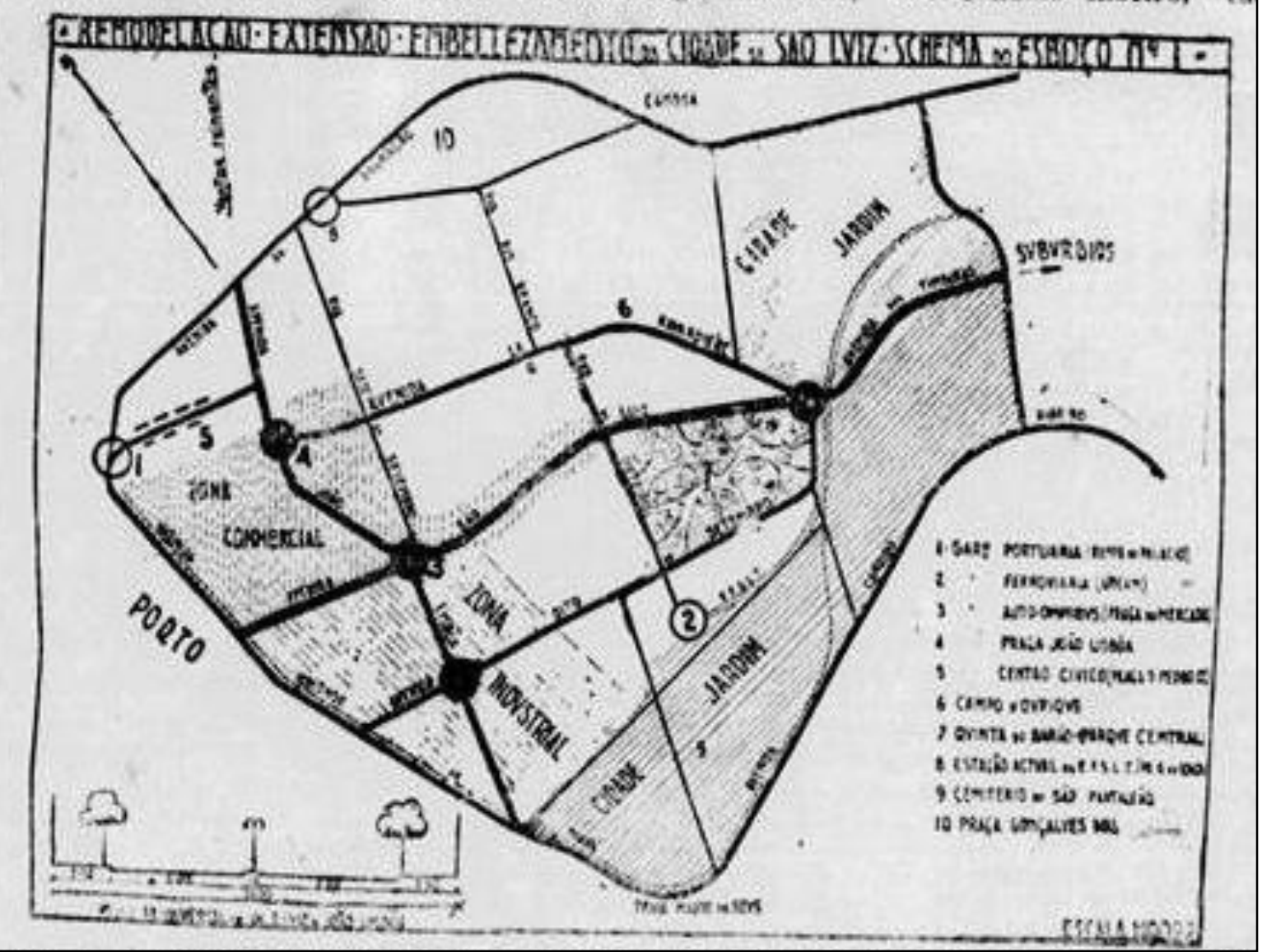

Fonte: O Imparcial (1937).

O projeto do então prefeito, intitulado "Remodelação, Extensão, Embelezamento da Cidade de São Luiz", esboçado em um croqui e publicado em fevereiro de 1937 pelo jornal O Imparcial, previa uma intervenção em diversas áreas da cidade, inclusive intervenções que estavam em curso como a do Mercado Público e do Matadouro Modelo e outras que seriam ainda construídas ou reformadas em importantes espaços públicos, como prédios, praças e vias da cidade onde se localizavam repartições públicas e que tinham grande movimentação de pessoas, a exemplo da Praça e Avenida João Lisboa, da Avenida Dom Pedro II (com a construção de um centro cívico), Rua Sete de Setembro, Rua Oswaldo Cruz, Avenidas Beira-Mar e João Pessoa, incluía a demolição do Palácio dos Holandeses, 
construção de um hotel e intervenções no cais do Porto e no entorno da linha férrea. Segundo Lopes (2013, p. 174),

A partir desses princípios projetuais, os quarteirões conformados pelos prédios de arquitetura tradicional luso-brasileira, não são tratados como elementos de composição do desenho urbano, mas como resultado da aplicação dos novos traçados à cidade. Este sistema de avenidas, por sua vez, facilitaria o tráfego eficiente entre as diversas zonas da cidade, conferindo a essas áreas salubridade, iluminação e arborização que, aliado à adoção de novos padrões estéticos para a arquitetura (Art Decò), emprestariam uma imagem de modernidade à cidade (LOPES, 2013, p. 174)

Era um projeto ambicioso, que olhava para o futuro da mobilidade urbana da capital maranhense; para isso, instituiu, através do Decreto n.ํ 233/1937, uma Comissão do Plano de Cidade, composta por sete membros, chamada à época de "Organismo Technico Municipal" pelo O Imparcial, que, em sua manchete sobre a comissão do plano, escreveu: "verdadeiro conselho technico, essa commissão vae agrupar valisosos elementos de reconhecida capacidade mental, independência e possuidores de accentuado sentimento esthetico" (COMMISSÃO, 1937, p. 2). O jornal se referia à capacidade intelectual e técnica dos membros da comissão, que além do próprio Saboya Ribeiro, era composta pelo Coronel Luso Torres (ex-prefeito e ex-interventor), os médicos Carlos Macieira e Heitor Pinto, o Industrial Américo Pacheco de Carvalho, o professor Luiz Rêgo e o engenheiro Pinheiro Costa.

A tentativa de modernizar São Luís, não apenas dando a ela um aspecto urbanístico novo, mas mirando a alteração dos costumes e hábitos, modernizando o seu sistema tributário, ordenando o comércio, a indústria e o transporte. Mas Saboya Ribeiro esbarrou no complexo arranjo político local e na sua classe dominante sobretudo os mandatários do Comércio que tinham fortes ligações com a oligarquia política local - que não concordavam com algumas práticas modernizantes e ideias promovidas pelo prefeito, que não logrou sucesso nos diálogos com essessegmentos.

O prefeito começou a ser criticado por diversos órgãos de imprensa do quais havia tido apoio no início de sua gestão, muitos termos depreciativos foram usados pela imprensa para qualificar o prefeito, "prefeito tentacular, arquiteto-embromistae moço-urbanista demonstravam a insatisfação e a descrença na expertise que julgava representar, além de demarcar os espaços de fala" (COSTA, 2016, p. 115). 
Saboya Ribeiro chegou a chamar os habitantes ludovicenses de "selvagens e sem cultura7", provocando a ira da elite local, da imprensa e de parte da população. As propostas saboyanas, como se viu, se basearam num paradigma moderno, com a construção de amplas avenidas, demolição e reconstrução de casarões em ruínas, higienização dos espaços e a valorização do acervo arquitetônico histórico. Em 21 de agosto de 1937, Saboya Ribeiro, sem apoio políticos e da população, pede exoneração a Paulo Ramos.

\section{A gestão Pedro Neiva e a São Luís “moderna” e funcional}

Com a saída de Saboya Ribeiro da prefeituta, Clodoaldo Cardoso ocupa então a cadeira de prefeito de São Luís interinamente após a saída de Ribeiro, até que, em novembro de 1937, Pedro Neiva de Santana ${ }^{8}$ é nomeado prefeito de São Luís, um nome que agradou a imprensa e as elites econômica e política local. Sua nomeação coincidiu com o golpe de 10 de novembro, que culminou com a instalação de um regime autoritário no Brasil.

Saboya Ribeiro deixou uma semente modernizadora importante que seria posta em prática numa escala maior por Pedro Neiva e Paulo Ramos. Na visão de Buzar (2000), a cidade ganhava uma nova fisionomia através de sua gestão, bem como the era imposto um rígido controle sobre as finanças.Pedro Neiva assume e continua as ideias e ações propostas iniciadas pelo seu antecessor, faz ajustes na legislação urbana, definindo critérios para isenções de impostos que "incentivam a verticalização no centro urbano e um novo zoneamento para a cidade" (LOPES, 2013, p. 206). Com o Decreto n. 330/1938, Pedro Neiva aprova um novo código de zoneamento para São Luís, o segundo na história da cidade, um zoneamento funcional que se limitava em quase toda sua totalidade à Zona Central, criada por Saboya Ribeiro no zoneamento de1936.

Outra característica desse instrumento era o incentivo à verticalização da cidade, definindo trechos onde não seriam permitidas construções novas com apenas um pavimento. Havia no Decreto 330/1938, segundo Burnett (2012, p. 33), "uma nova zona residencial, compreendida pelas ruas de Santana, Passeio,

\footnotetext{
${ }^{7}$ Manchete "O Protesto do Commercio no caso dos insultos da mensagem de Saboya Ribeiro", doJornal Pacotilha, Ano LVII, n.. 899, de 5 de agosto de 1937.

${ }^{8}$ Pedro Neiva de Santana nasceu em Nova lorque (MA) no dia 27 de setembro de 1907, filho do coronel Manuel José de Santana e de Ana Neiva de Santana. Fez os primeiros estudos em Floriano (PI) e no Liceu Maranhense, em São Luís. Transferindo-se para o Rio de Janeiro, então Distrito Federal, ingressou em 1929 na Faculdade de Medicina, pela qual se diplomou, especializando-se depois em medicina legal (FUNDAÇÃO GETÚLIO VARGAS, 2019)
} 
Ribeirão, São Pantaleão e Direita, onde medidas legais impediam a presença de construções populares, como cortiços e casas térreas", o que incentivava uma renovação arquitetônica nosprédios.

Figura 04 - Mapa baseado no Decreto ํㅜ 330/1938 que instituiu o Zoneamento

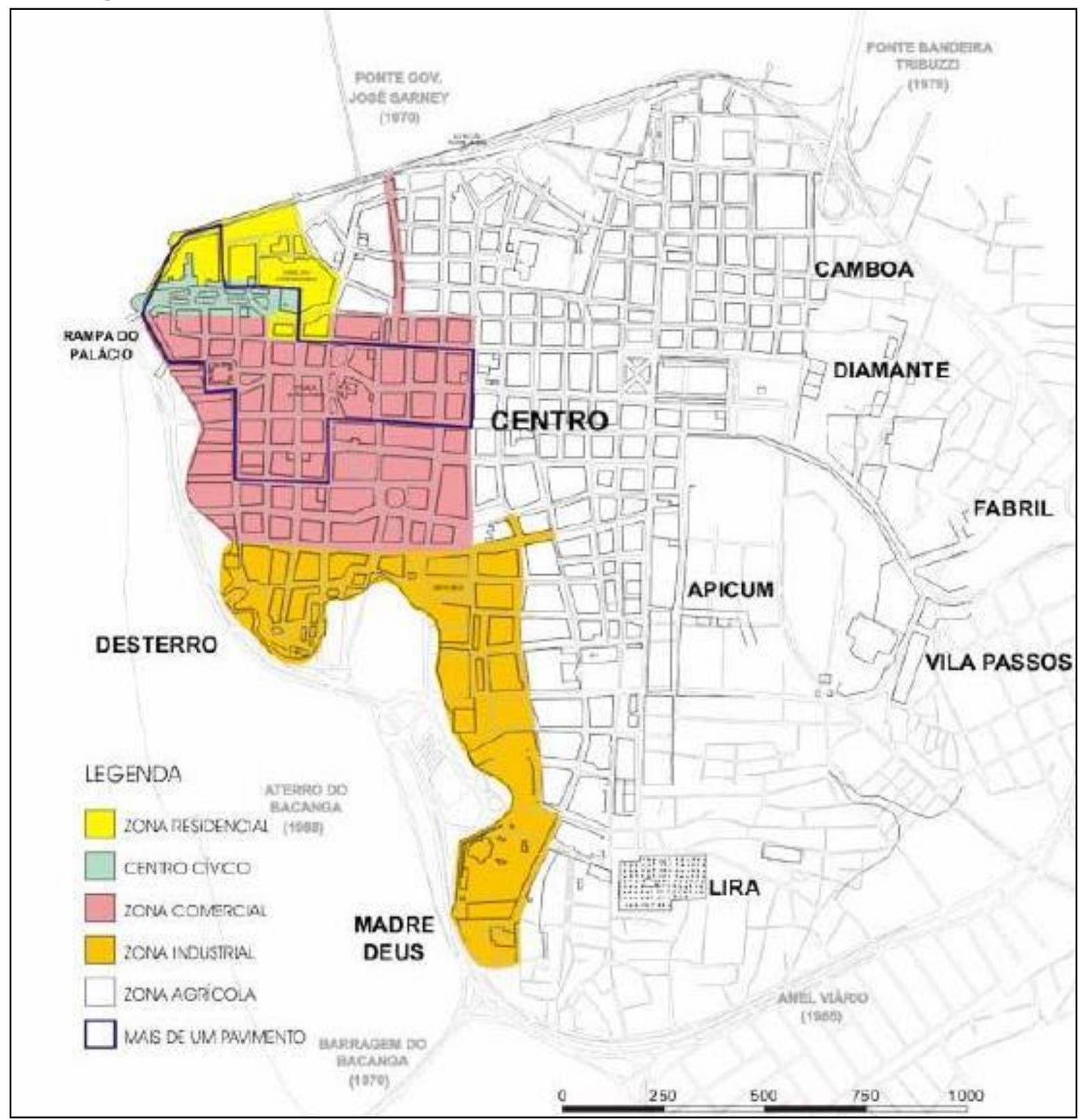

Fonte: Lopes (2013, p. 208).

O Zoneamento de Pedro Neiva instituiu um Centro Administrativo ou Centro Cívico (legado de Saboya Ribeiro) bem como 4 zonas: a Zona Comercial, a Zona Industrial, a Zona Residencial e a Zona Agrícola. As intervenções que seriam derivadas deste zoneamento privilegiariam a zona central como já foi dito, menosprezando a totalidade da ilha, como as zonas suburbana e rural criadas por Saboya Ribeiro. 
O Novo Plano da Cidade de Pedro Neiva estabeleceu uma série de providências de cunho higienista com a inserção de novas estruturas em prédios e edifícios em substituição às antigas, além de transformações no sistema viário da cidade, situação semelhante ao que vinha acontecendo em bairros e avenidas de outras cidades brasileiras como Recife, São Paulo, Salvador e Porto Alegre.

Por ser médico de formação, Pedro Neiva imprimiu as seguintes mudanças de caráter higienista: reforma dos hospitais Geral e Infantil, no Instituto Oswaldo Cruz, taxação de cortiços e casas mais humildes, medidas em relação à ventilação e iluminação de ambientes internos e a ampliação de arborização de avenidas, ruas e praças da cidade. Segundo Lopes (2013, p. 213),

\begin{abstract}
As substituições de estruturas tradicionais por novos edifícios, realizadas no início da década de 1940, incluíram a demolição do antigo mercado, ainda na administração de Saboya Ribeiro, que funcionava no terreno da extinta Companhia de iluminação e Gás, o gazômetro, para a construção de um novo e moderno Mercado Central (...) O 'palácio dos holandeses' também demolido por Saboya Ribeiro, daria lugar à nova sede da Associação Comercial - que tanto havia protestado contra as mudanças e impostos de Saboya - o palácio do Comércio, edifício de linhas ArtDecò, construído pelo Município e cedido à Associação. Era nesse verdadeiro 'palácio encantado da cidade' que a burguesia local promovia os seusbailes.
\end{abstract}

Durante os anos 1940, São Luís começou sua expansão para além dos limites do que hoje equivale ao Anel Viário, que foi proporcionada com a utilização dos bondes elétricos até o bairro do Anil, da Ferrovia São Luís-Teresina, e a abertura de novas e modernas avenidas, como a Getúlio $\operatorname{Vargas}^{9}$ e a João Pessoa, que facilitou o deslocamento dos indivíduos, por meio de um transporte público, e organizou a ocupação de um local, onde estavam situadas chácaras, quintas e sítios, que eram mais distantes do Centrohistórico.

A Avenida Getúlio Vargas foi construída com duas largas vias para linhas do bonde e veículos automotivos, canteiros centrais gramados com jardins e árvores, e calçadas laterais largas. A construção desta via foi uma grande influência que serviu de inspiração para a abertura de novas e importantes vias na cidade.

A pavimentação desta avenida ensejou uma mudança marcante na paisagem do lugar, isto é explicado pelo surgimento de construções amplas e confortáveis em suas margens, substituindo boa parte dos sítios e chácaras que ali existiam. Algumas dessas novas construções eram representadas ao longo da avenida por

\footnotetext{
${ }^{9}$ Em relatório apresentado ao Presidente da República em 1942, Paulo Ramos assim escreve sobre a construção da Avenida Getúlio Vargas em 1939: "Pavimentada com paralelepípedos rejuntados e cimento, dispõe de duas superfícies de rolamento de 7 metros cada uma, separada por uma série de abrigos centrais de 4 metros de largura, gramados ajardinados, medindo os passeios 3 metros de cada lado (RAMOS, 1942).
} 
residências de arquitetura característica, predominando o estilo moderno, mas também com a presença dos estilos neoclássico e art decò, residindo ali famílias com grande poder aquisitivo.

Figura 05 - Avenida Getúlio Vargas em São Luís nos anos 1940.

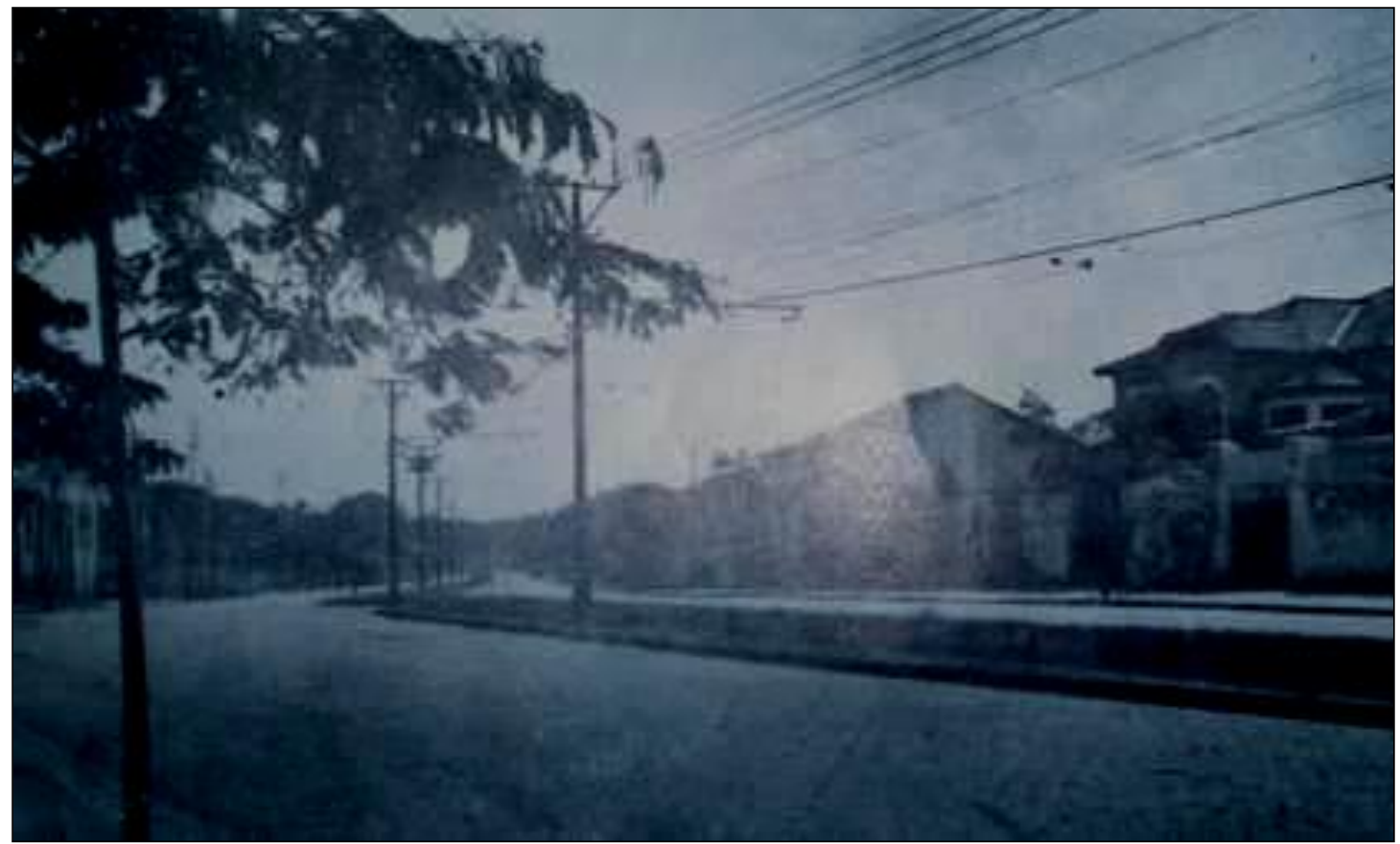

Fonte: Jorge (1950)

Figura 06 - Planta da cidade de São Luís em 1950

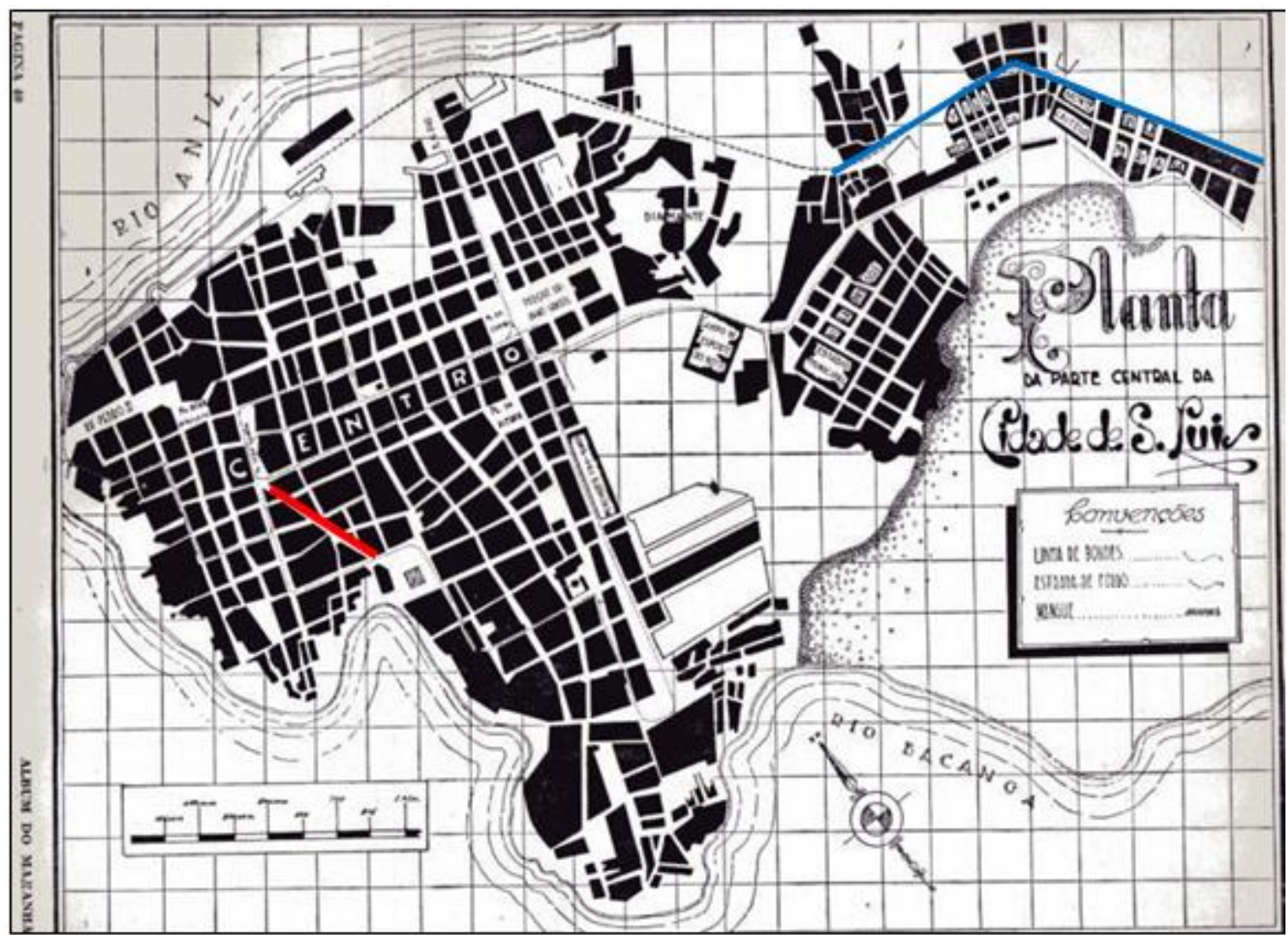

Fonte: Jorge (1950). 
O crescimento urbano de São Luís teve como uma de suas maiores expressões a ocupação do eixo Centro-Anil. Segundo Gomes (1988), nas décadas de 1920 e 1930 São Luís possuía um lento crescimento da área urbana, permitindo que a cidade atraísse recursos direcionados à urbanização, como algumas tímidas melhorias em saúde, educação, transporte, energia e saneamento.

A partir da década de 1940, a cidade de São Luís "expande-se numa faixa de aproximadamente 13 quilômetros de extensão" (GOMES, 1988, p. 21-22), sendo que a topografia pouco favorável, situada no divisor de águas dos dois principais rios da ilha, fez com que este crescimento se direcionasse aosmanguezais.

A Planta de São Luís de 1950, publicada no Álbum do Miécio Jorge, traz duas inovações em relação aos mapas publicados anteriormente; uma é o traçado da Avenida 10 de Novembro (atual Avenida Magalhães de Almeida ${ }^{10}$ - linha vermelha na figura 6) em diagonal, essa construção constituía a proposta de intervenção urbana idealizada por Saboya Ribeiro em 1937 e implementada por Pedro Neiva e Paulo Ramos em 1941, criando uma ligação entre a Praça João Lisboa e o Mercado e outras áreas da cidade, provocando uma ruptura com o traçado urbano dos séculos XVIII e XIX em virtudeda demolição de muitos casarões, o que possibilitou a incorporação de construções em estilo modernista. A outra inovação na Planta é o novo eixo viário de expansão urbana de São Luís, a Avenida Getúlio Vargas (linha azul na figura 6), observada na imagem dafigura 5. A toponímia chama atenção nesta área da cidade, com os bairros Vila Operária, Vila Mariana e Monte Castelo, este último o mais importante devido ao seu pioneirismo com rápida urbanização para além dos limites do Anel Viário entre os anos 1950 e 1980.

$\mathrm{Na}$ Era Vargas, ainda houve ações voltadas à produção de habitações ao público assalariado a partir dos Institutos de Aposentadorias e Pensões (IAP's), que foram criados em 1933 para fomentar única e exclusivamente a assistência previdenciária e médica a seus associados. Desta forma, “em 1937, os IAPS passaram a atuar no campo da habitação, onde poderiam investir até $50 \%$ de suas reservas para o financiamento habitacional" (RUBIN; BOLFE, 2014, p. 205). O Estado Novo viu ali uma possibilidade de iniciar uma política urbana de habitação a fim de exercer um maior controle social nas cidades que começavam a adquirir maior importância na constituição da sociedadebrasileira.

10 Sobre a construção e modernização da avenida em questão, conferir o trabalho de Pflueger e Furtado (2017). 
Com a queda de Vargas em 1945 e a volta da democratização brasileira, São Luís retorna a uma instabilidade política nas gestões municipais que não possuíam planos urbanos mais ousados, imperando apenas os reclamos da problemática cotidiana localizada. Mesmo assim, em 7 de setembro de 1945, é inaugurada a Cidade Balneária do Olho D’água, construída pelo governo com via de acesso para o local, então distante da vida urbana, mas que "comprovará a relevância urbana que aquela região terá para a futura expansão de São Luís" (BURNETT, 2012, p. 96).

Paralelo à nova vocação dos IAP's para a produção imobiliária surge em maio de 1946, no Governo Dutra, a chamada Fundação da Casa Popular (FCP), instituída pelo Decreto-Lei n. 9.218, que tinha por objetivo fomentar investimentos na área da habitação popular para parcelas da população de baixa renda. Segundo Vasconcelos (2014, p. 37), "a cidade de São Luís foi contemplada com apenas um conjunto de 50 casas, localizado no Monte Castelo", nas proximidades do prédio do Serviço Nacional de Aprendizagem Industrial (SENAI), conhecido entre os moradores locais pelo nome de "Popularzinha". Entre os estados da Federação que receberam conjuntos pelo FCP, o Maranhão foi aquele contemplado com menor quantidade de habitações.

Os anos que sucederam a Era Vargas no Maranhão até $1975^{11}$, em especial na cidade São Luís, foram marcados pela ausência de um planejamento voltado para o espaço urbano e outros territórios do município. Mas em 1958 houve a idealização de uma expansão para novos territórios na capital maranhense, O Plano de Expansão do engenheiro Ruy Mesquita, que de um lado estabelecia estratégia para ocupação do norte do município em direção às praias, atravessando o rio Anil com a construção de uma ponte e de outro lado um crescimento para a área conhecida como Itaqui-Bacanga com toda a sua potencialidade portuária. O plano de Mesquita foi considerado arrojado para a época e em alguns aspectos se baseou nas ideias de Saboya Ribeiro no seu Plano de Remodelação de São Luís, como a construção de um Centro Cívico e a construção de uma grande avenida que contornaria todo o centro antigo, conhecida hoje como Anel Viário.

\section{Considerações Finais}

O Período varguista foi marcado pelo discurso e pela prática do saber urbanístico, com a participação ativa de técnicos e intelectuais na construção e

\footnotetext{
${ }^{11}$ Ano da publicação do primeiro Plano Diretor de São Luís sob a gestão do prefeito Haroldo Tavares.
} 
consolidação de planos estratégicos para as cidades brasileiras, tendo como base uma racionalidade moderna.

Houve uma política estatal abrangente de remodelação urbana que teve a influência estética do movimento moderno, priorizando demolições, reconstruções e a expansão de áreas centrais, zoneamentos com a setorização de atividades, higienização dos centros urbanos e seus respectivos códigos de posturas, códigos edificatórios, alargamento de avenidas, novos bairros residenciais para as classes mais abastadas e bairros operários, dentre outras questões, tudo com o intuito de se instaurar uma nova ordem social e espacial a partir de um viés autoritário e racionalista.

Não obstante, Vargas nomeou aos estados interventores que, através de relatórios periódicos e detalhados the repassavam tudo que era realizado, uma estratégia de controle do território que teve apoio de militares, pesquisadores e intelectuais.

Nesta perspectiva, o trabalho de Paulo Ramos no Maranhão foi inovador à medida que imprimiu e consolidou grandes obras - e em certa medida uma nova mentalidade - na capital e no interior do estado. A figura de Saboya Ribeiro também representou uma ruptura com a velha forma de se pensar a cidade de São Luís, isto ficou evidente com a elaboração de um abrangente e diversificado Código de Posturas em 1936, uma lei que primou pela modernização do espaço urbano e sua higienização, sem esquecer a importância do patrimônio arquitetônico com seus casarões, trapiches e sua memória coletiva.

Saboya Ribeiro inovou ao elaborar um zoneamento que viu o município em sua totalidade e não apenas o centro antigo, lugar com maior adensamento populacional na época. Propôs e imaginou uma imensa via que circundaria todo o território do centro antigo, contribuiu para ajustar e equilibrar as contas do município e logrou êxito em muitas diligências e fiscalizações na cidade, sobretudo em casarões com riscos de desabamento e em incêndios comuns na zona rural, onde a pobreza e a insalubridade imperavam. No entanto esbarrou nos interesses da elite econômica e comercial na cidade, ligada umbilicalmente às oligarquias políticas locais que viam em suas ideias modernizantes uma ameaça para seus projetos.

Pedro Neiva de Santana, sucessor de Saboya Ribeiro, conseguiu levar adiante muitas ideias do engenheiro-arquiteto cearense e foi uma figura que conseguiu dialogar com setores políticos locais, com a elite comercial e a imprensa, o que foi decisivo para a longevidade de sua gestão. Nela se destacaram a 
formulação de um zoneamento funcional para a cidade que privilegiou territórios onde habitavam as classes média e alta, medidas higienistas e de construção de casarões em estilo moderno como os que se viam na então nova Avenida $10 \mathrm{de}$ novembro e a pavimentação do caminho grande, transformado em Avenida Getúlio Vargas, o grande eixo de expansão urbana ludovicense período de 1940 à 1960.

Não é exagero afirmar que, ao menos no discurso, a era Vargas e sua influência no planejamento urbano de São Luís foi uma das mais emblemáticas tentativas de modernização do território na cidade no século $\mathrm{XX}$, as ideias oriundas de intelectuais e técnicos de urbanismo desta época ressoaram por décadas ao influenciar, em alguma medida, o Plano de Expansão de Ruy Mesquita e o Plano Diretor de 1975.

\section{REFERÊNCIAS}

A CIDADE de São Luiz. O imparcial. São Luís, n. 5.498, 26 fev. 1937, p. 1.

Disponívelem:<memoria.bn.br/DocReader/docreader.aspx?bib=107646\&pasta=ano\%20193 \&pesq=\%22A\%20Cidade\%20de\%20São\%20Luiz\%22>. Acesso em 22 mar. 2019.

AS OBRAS de demolição dos pardieiros de S. Luiz. O Imparcial. São Luís, n. 5.591, 1 jun, 1937, p. 2. Disponível em:<http://memoria.bn.br/DocReader /docreader.aspx?bib=107646\&pasta=ano\%20193\&peq=\%22A\%20Cidade\%20de\% 20 São\%20Luiz\%2. Acesso em 22 mar. 2019.

BURNETT, F. L. São Luís por um Triz: Escritos urbanos e regionais. São Luís: EDUEMA, 2012. $171 \mathrm{p}$.

BUZAR, B. Prefeitos de São Luís no Século XX. O Estado do Maranhão. São Luís, 1 out. 2000, Caderno Especial.

COMMISSÃO DO PLANO DE CIDADE. O Imparcial. São Luís, n. 5.539, 7 abr. 1937, p. 3.

Disponível em: <memoria.bn.br/DocReader/docreader.aspx?bib

=107646\&pasta=ano\%20193\&peq\%20=\%22A\%20Cidade\%20de\%20São\%20Luiz\%2>

Acesso em 22 mar. 2019.

COSTA, M. L. O projeto de modernização de São Luís nos anos Paulo Ramos (19361945). 2016. 161f. Dissertação (Mestrado em História). Centro de Ciências Humanas, Universidade Federal do Maranhão - UFMA, São Luís, 2016.

FERREIRA, E. P. A Mística do Parentesco - uma genealogia inacabada.

Piauí/Maranhão/Rio de Janeiro e São Paulo. Vol. 4. São Paulo: Corrêa Lago, 1987. 240p.

Disponível em:<https://www.parentesco.com.br/>. Acesso em 20 fev. 2020.

FOUCAULT, M. História da sexualidade 1: a vontade de saber. $7^{a}$ ed. Rio de Janeiro: Paz e Terra, 2018. 176p. (Coleção Biblioteca de Filosofia).

FUNDAÇÃO GETÚLIO VARGAS - FGV. (Centro de Pesquisa e Documentação de História Contemporânea do Brasil - CPDOC). Pedro Neiva de Santana: perfil biográfico. Rio de Janeiro, 2019. Disponível em: <http://www.fgv.br/CPDOC/BUSCA/dicionarios/verbetebiografico/pedro neivadesantana> Acesso em: 30 jan. 2020. 
GOMES, J. T. P. Síntese Histórica da Formação Urbana de São Luís. Revista FIPES. São Luís, v. 3, n. 2, p. 17 - 25, Jul / Dez, 1988.

IANNI, O. Estado e planejamento econômico no Brasil. Rio de Janeiro: Editora UFRJ, 2010. 332p.

JORGE, M. Álbum do Maranhão 1950. São Luís, s. ed, 1950.

LEME, M. C. S. Urbanismo no Brasil (1895-1965). 2. ed. Salvador: EDUFBA, 2005. 599p.

LOPES, J. A. V. São Luís, Capital Moderna e Cidade Colonial. Antônio Lopes da Cunha e a Preservação do Patrimônio Cultural Ludovicense. São Luís: Fundação Municipal de Cultura/Editora Aquarela, 2013. 328p.

MANZO, R. A Arquitetura na construção da imagem do Estado getulista: Rio de Janeiro (1930-1945). 2011. 309f. Tese (Doutorado em Arquitetura e Urbanismo). Universidade Presbiteriana Makenzie, 2011.

MEIRELES, M. M. História do Maranhão. São Paulo: Siciliano, 2002. 392p.

MONTELLO, J. A cidade que não quer ser nova. Revista Careta, Rio de Janeiro n. 1.535, Ano XXX, p. 24-25, 20 nov. 1937. Disponível em:

<objdigital.bn.br/acervo_digital/div_periodicos/careta/careta_1937/careta_1937_1535.pdf> Acesso em 30 mar. 2019.

OLIVEIRA, F. "Dêem-me Ademir e eu darei o campeonato". In: CASTRO, A. C. et. al. Brasil em desenvolvimento 2: instituições, políticas e sociedade. Rio de Janeiro: Civilização Brasileira, 2005. p. 379-391.

PFLUEGER, G.; FURTADO, L. As imagens do moderno em São Luís pelo álbum de Miécio Jorge, de 1950. Revista Amazônia Moderna, Palmas, v.1, n.1, p.68 - 83, abr/set. 2017. Disponível em:<https://sistemas.uft.edu.br/periodicos/index.php> Acesso em 10 jan. 2020.

QUINTO JUNIOR, L. P. Nova legislação urbana e velhos fantasmas. Estudos Avançados, São Paulo, v. 17, n. 47, 2003. Disponível em:<http://www.scielo.br/pdf/ea/v17n47/a11v1747.pdf. Acesso em 19. abr. 2020.

RUBIN, G. R.; BOLFE, S. A. O desenvolvimento da habitação social no Brasil. Ciência e Natura, Santa Maria v. 36, n. 2 mai - ago. 2014, p. 201-213. Disponível em:< oaji.net/articles/2017/1602-1487076445.pdf>. Acesso em 29 jan. 2020.

SCHWARCZ, L. M.; STARLING, H. M. Brasil: uma biografia. São Paulo: Companhia das Letras, 2015. 694p.

SELBACH, J. F. (Org.). Códigos de Posturas de São Luís/MA. São Luís: EDUFMA, 2010. $304 p$.

VASCONCELOS, P. E. S. Política habitacional do Estado autoritário em São Luis (19641985). 2014. 145f. Dissertação (Mestrado emDesenvolvimento Socioespacial e Regional. Universidade Estadual do Maranhão,UEMA, 2014.

VILLAÇA, F. Uma contribuição para a história do planejamento urbano no Brasil. In: DEÁK, Csaba; SCHIFFER, Sueli Ramos (Orgs.). O processo de urbanização no Brasil. 2. ed. São Paulo: EDUSP, 2010. p. 169-243. 


\section{NOTAS DE AUTOR}

\section{CONTRIBUIÇÃO DE AUTORIA}

Luiz Eduardo Neves dos Santos - Concepção. Pesquisa Histórica, iconográfica e bibliográfica. Coleta de dados, Análise de dados, Elaboração do manuscrito e revisão.

Maria Clélia Lustosa Costa - Análise de dados, elaboração do manuscrito. Participação ativa da discussão dos resultados; aprovação da versão final do trabalho.

\section{FINANCIAMENTO}

Este artigo é resultado de discussões no doutoramento do autor principal com sua orientadora e também coautora neste manuscrito, tendo apoio financeiro com Bolsa de estudos concedida pela Fundação de Amparo à Pesquisa e ao Desenvolvimento Científico e Tecnológico do Maranhão - FAPEMA.

\section{CONSENTIMENTO DE USO DE IMAGEM}

Não se aplica

\section{APROVAÇÃO DE COMITÊ DE ÉTICA EM PESQUISA}

Não se aplica.

\section{CONFLITO DE INTERESSES}

Sem conflito de interesses.

\section{LICENÇA DE USO}

Este artigo está licenciado sob a Licença CreativeCommons CC-BY. Com essa licença você pode compartilhar, adaptar, criar para qualquer fim, desde que atribua a autoria da obra.

\section{HISTÓRICO}

Recebido em: 04-03-2020

Aprovado em: 20-05-2020 